cacao industry. This achievement has been made possible by working in the closest collaboration with the Departments of Agriculture, from which the Institute has taken over and developed several lines of investigation initiated prior to 1944 .

Much remains to be explored in connexion with swollen-shoot disease; but the field vectors are now known and considerable data have been accumulated concerning the viruses and virus strains causing this disease. While no example of immunity in Th. cacao has been discovered, work on tolerance is leading to results which may be of more than academic interest. Control of the disease in the field by rogueing infected trees has been proved, and this method is being adopted with vigour by both the British and French West African Governments.

Although no practical control of capsid pests of cacao has yet been proved, small-scale trials with recently developed insecticides are giving promising results. The system of cacao farming adopted by the Africans and their lack of mechanical skill will, however, act as a severe handicap to the use of mechanical apparatus on which chemical control so largely depends. Unfortunately, no success has yet been obtained on the biological control of cacao capsids. The discovery by the Institute that much of the damage formerly ascribed to capsids alone is, in fact, due to subsequent invasion by the fungus Calonectria rigidiuscula (Berk et Brme) Sacc. further complicates the problem.

Definition has now been given to soils in West Africa which are suited to permanent cacao cultivation, and it has been shown that the presence of virus disease or capsid pests is in no way dependent on the type of soil on which eacao is grown. A rapid method of soil surveying, based on the American system, has been evolved by the Institute, and the Gold Coast and Nigerian Governments are now considering putting into effect soil surveys, one object of which would be to assess the area of actual and potential land suited to permanent cacao cultivation.

A valuable collection of varieties of $T h$. cacao has been introduced from the West Indies, South and Central America, and is now established at Tafo. Marked differences in growth are already apparent, and many varieties exceed the West African Amelonado (a lower Amazon type) in robustness. Seven species of Theobroma other than $T h$. cacao have also been introduced. The collection is by no means complete; but it will be surprising if that now established by the Institute does not produce plant material of the utmost value either through resistance to diseases or pests, or through increased yields. There is the further possibility that certain varieties may thrive on soils which are not suitable for the growth of West African Amelonado, and thereby extend the range of cacao cultivation.

An ordinance passed in March 1947 by the Gold Coast Government provides for the legal establishment of the Institute and for a statutory committee to control and administer it. After meeting the expenditure on the surveys, the recurrent expenditure of the Institute during $1944-47$, and the extraordinary expenditure at Tafo, a sum of some $£ 850,000$ remains. The interest from this, fortified by the periodic sale of investments, will provide the Institute with means of meeting recurrent expenditure over the next twenty years.

1 Report on Cocoa Control in West Africa, 1939-43, and statement on Future Policy. Cmd. 6554. (Iondon: H.M. Stationery Office.)

${ }^{2}$ Report and Proceedings of the Cocoa Conference, May-June, 1945 : Colonial No. 192. (London: H.M. Stationery Office.)

\section{EXHIBITION OF INDIAN ART}

T must at the outset be confessed that to those who know India the Exhibition of Art from India and Pakistan at the Royal Academy, London, is a little disappointing. Since architecture could not be exhibited, it could not really be comprehensive of Indian art; but even so, and in spite of a few superb examples of the carvers' and the armourers' craft, some fine cast bronze and a few magnificent carpets, the bulk of the exhibition consists of sculpture and of painting in miniature. Textiles in general are poorly represented. Nor is all the exhibition very happily displayed. In the first gallery, the material on which small objects are shown is badly chosen in regard to colour, and the labelling is sometimes questionable ; the Mohenjodaro copper bull (No. 5) is probably a species of sheep or goat, and the so-called girdle (No. 29) is really too long ( $4 \frac{1}{2} \mathrm{ft}$.) for that purpose, and was probably a neck ornament like some very similar that still survive in at least one marginal area.

The sculpture is inevitably disappointing. Reft from its architectural background, most of it on a very small scale, it would have stood more concentrated grouping than it has received, and it is little helped by a background which fails to show it up. How much difference an appropriate background can make can be judged by the marble arch from Bikanir (No. 279). Even in its own surroundings, and seen on the scale of Ellora, Madura, or Seven Pagodas, Indian sculpture is not easy to appreciate-probably because it is impersonal in style, and the individuality one looks for in European sculpture is suppressed here and subordinated to an abstraction. Indian sculpture bears perhaps to European much the same relationship as the ballet bears to the drama: it is generalized, and individuality is absent. It is possibly significant, therefore, that some of the most attractive sculptures are figures which have lost their heads, like the red sandstone Bodhisattva (No. 207), which is perhaps the best piece in the exhibition, though the magnificent horse from Konarak (No. 276) runs it very close. This horse, it is true, has a head; but it is a live, individual head and it is difficult to suppose that the living prototype had not a personal name given him. An eleventh-century basalt Brahman from Orissa (No. 302) is notable, and among the wood carvings a sixteenth century carving of Krishna (No. 293) in the same gallery.

But the most substantial part of the exhibition is the very large series of Rajput and Mughal paintings. These have much in common with the miniatures in illuminated medieval manuscripts, and the fascinstion of their execution and conception is often en. hanced by their naïvety. On the whole, the Rajasthani and Kangra paintings please more than the Mughal. This is perhaps to be expected, since Muslim painters must often have worked with some misgiving at their infringement of religious injunction, while no such inhibition would trouble a Hindu. There was some. thing particularly suggestive of a Book of Hours about No. 662-Krishna sheltering Radha from the rain, and the Kangra paintings of the heroine, the cat, and the lovebird (No. 652), of Krishna and Radha by moonlight (No. 655), of the messenger's arrival in a storm (No. 680), or of Krishna with the gopas (No. 684), struck one in passing as particularly attractive. If one must select among the Mughal paintings, Mansur's hornbill (No. 911) and the portraits of Murad on an elephant (No. 1100), of Muhammad 
Riza Kashmiri (No. 1107), of Khan-i-Dauran (No. 1118), of Shah Daulat holding a globe (1124), may be mentioned, while two drawings of a lady at her toilet and a boy holding fruit (No. 1139) are noticeable for the effect obtained with a greater economy of line than the general style of the period would lead one to expect. Very interesting were drawings of Europeans as seen by seventeenth century Indian painters, and the unexpected Mughal copies of Dürer's "Virgin and Child" (No. 1217) and his "St. John the Evangelist" (No. 820), and a sixteenth century Indian drawing of St. Matthew.

But all these very remarkable series of Indian paintings suffer from inadequate description. More explanatory labelling would not have disturbed the general effect, and apart from the crying need for it in regard to so many of the paintings, it should be explained, for example, that the thumb ring (No. 793) was used for drawing a bow ; unnecessary inaccuracies, such as describing an obvious pheasant as a "jungle. cock" (No. 896), could easily have been avoided. Moreover, some of the miniatures with the greatest intricacy of detail (for example, No. 534) are hung too far above the eye line, and it is tiresome to find the order of pictures in the catalogue failing from time to time to correspond with the order in which they are hung.

No notice of this exhibition would be complete without mention of the admirable Mughal jade and crystal vessels in Gallery X-No. 1088 in particularand of the Girdlers' Company's Indian carpet woven for them in 1634. A good many of the modern Indian paintings could have been omitted without loss. On the other hand, it was a pleasant surprise to meet the paintings by British artists in India, the Zoffanys, including Colonel Mordaunt's Cock Match in particular, Tilly Kettle, George Chinnery, and the rest. It is a pity that in Clive's set of ivory chessmen exhibited in the same room the respective sides were mixed when they were set out.

It is to be feared that this account may read a little captiously. That is not ingratitude for such a magnificent feast of the beautiful as has been provided, but rather a feeling that it has not been cared for quite as devotedly as it deserves.

\section{J. H. HuTtoN}

\section{OBITUARIES}

Prof. E. C. C. Baly, C.B.E., F.R.S.

THE death on January 3 of Prof. E. C. C. Baly, emeritus professor of inorganic chemistry in the University of Liverpool, deprives the scientific world of a vivid and stimulating personality. He was born in 1871, his father, E. E. Baly, being an official of the Bank of England in London. He obtained his scientific training at University College, London, but instead of taking the conventional B.Sc. course he proceeded direct to the Institute of Chemistry qualification. Attracted always to research, particularly in its more romantic aspects, Baly must have found the atmosphere under Ramsay at University College very congenial. Like his chief, Baly loved an element of daring in his investigations, and generations of Liverpool students rejoiced to hear him tell the story of the discovery of the rare gases. This he did with obvious enjoyment and conscious artistry. It was at University College that he acquired his great skill as an experimenter. Indeed, his powers as a glass-blower became legendary. Even after he had suffered the loss of an eye as a result of an explosion in the laboratory, his skill was unimpaired.

Baly was one of the pioneers of spectroscopy. His work on the spectra of the rare gases was a model of its kind, and showed how the artistic side of his temperament was matched by a capacity for careful and precise work of an exhausting nature. He early showed an interest in absorption spectra in relation to chemical constitution, and a long series of papers with colleagues who later earned great distinction laid the foundations of a subject which has grown increasingly important. Baly was elected a fellow of the Royal Society in 1909. He held the post of assistant professor of chemistry and lecturer in spectroscopy during 1903-10 at University College. In 1910 he succeeded Campbell Brown as Grant professor of inorganic chemistry at Liverpool, and held the chair until his retirement in 1937.

Baly's "Spectroscopy" first appeared in 1905 and earned a great reputation as a valuable monograph. The second edition (1912) was nearly 700 pages in length, and the third edition appeared in three volumes in 1927. A fourth volume on absorption spectra of organic compounds was projected, but by that time Baly had transferred his main interest to photosynthesis, a book on which appeared in 1940 . The attempt to summarize the vast literature of spectroscopy was a tremendous task, necessitating for a chemist unusually wide reading of physical and astrophysical papers. Over many years Baly prepared reviews of the progress of inorganic chem. istry for the Annual Reports of the Chemical Society. Although many will remember him primarily as an adventurous researcher, his great contributions as a scholar should not be forgotten.

During the First World War, Baly became deputy inspector of high explosives for the Liverpool area, and at the end of the War he was awarded the C.B.E.

The post-war 'bulge' found the research laboratories at Liverpool crowded with keen ex-Servicemen, and Baly at the height of his powers. With characteristic courage he threw himself into the very difficult task of imitating in the laboratory the photosynthetic processes occurring in the living plant. In this work he was for a time joined by Prof. (now Sir Ian) Heilbron. The results of these and later researches attracted attention all over the world. They gave a powerful impetus to the continuing attack on a very complicated problem about which much still remains to be elucidated.

Baly's great personal charm, his enthusiasm and his persuasive advocacy, his skill as a musician and his feats as a mountaineer, his verve as a scientific worker and his labours on the councils of the Chemical Society, the Royal Institute of Chemistry and the British Association of Chemists will preserve his memory in many different circles. During his twentyseven years at Liverpool he gave distinguished service to the University in many capacities.

In 1902 Baly married Miss Ellen Agnes Jago, who, with four sons, survives him. R. A. Morton

\section{Sir Robert Greig}

By the death on November 29 of Sir Robert Blyth Greig, Great Britain has lost a very eminent administrator who in particular did much to further agricultural education and research. A son of George Greig, of Balcurvie in Fife, he was born in March 